\title{
Consensos Brasileiros: Propriedade e Pertinência
}

\section{editorial}

A

PRIORI A REUNIÃO DE UM GRUPO de especialistas em torno de determinado tema ou área de interesse - a maioria das vezes ainda não resolvido ou então controverso -, buscando estabelecer normas e diretrizes consensuais para sua aplicação e subsequente aproveitamento por outros interessados, parece uma política de significativo interesse comunitário que deva ser não somente elogiada mas, principalmente, estimulada para que ocorra mais freqüentemente e em condições mais apropriadas.

Acredito que sociedades médico-científicas tenham, até como obrigação, a incumbência de desenvolver, discutir e divulgar normas, diretrizes e outras informações consensuais que possam esclarecer e atualizar seus associados e, direta ou indiretamente, beneficiar a população como um todo.

Assim, há de se ver com bons olhos a intensa e freqüente movimentação em torno de tais empreitadas que vêm se desenvolvendo no âmbito de nossa sociedade e de outras congêneres. Esta pletora de informações importantes justificou à Comissão Editorial a possibilidade de publicá-las em números especiais de nossa revista, de forma original ou mesmo reprisando publicações anteriores. A idéia, iniciada já na edição de Fevereiro deste ano e a ser repetida na edição de Agosto, simplesmente visou englobar em um ou mais números dos $\mathrm{ABE} \& \mathrm{M}$ um conjunto de normas e diretrizes que pudessem ser de beneficio na prática diária da endocrinologia e metabologia clínica. As manifestações positivas recebidas por boa parte de nossos associados (inclusive de colegas de outras especialidades que solicitaram exemplares para uso próprio ou de seu grupo) são prova do sucesso desta iniciativa.

Entretanto, sem desejar entrar no mérito científico específico de tais consensos, devemos tecer algumas considerações até para justificar algumas das matérias incluídas no presente número da revista. Dos manuscritos enviados contendo os consensos recentemente publicados, o de Obesidade foi solicitado diretamente por mim e os dois sobre Diabetes (Complicações e Gestacional) foram submetidos espontaneamente. Como em tese (e pela própria definição) refletiam um Consenso - a opinião abalizada de um grupo de especialistas reunidos para decidir sobre um tópico específico -, e até para agilizar publicações tão importantes, achei óbvio e legítimo não submetê-las ao crivo de revisores, a não ser para eventuais correções gramaticais ou de estilo, e editorá-las no formato como foram enviadas. Para isso supus (e continuo supondo) que uma Comissão de Redação e de Revisão de cada Consenso estivessem presentes e tivessem feito tal trabalho. 
Em teoria, para que Consensos Brasileiros (ou Latino-Americanos) sobre determinado assunto possam ser considerados significativos e resolutivos, e tenham assim força e poder de representação, eles devem expressar a conduta da Sociedade MédicoCientífica envolvida e, mais do que isso, a dos respectivos departamentos, capítulos ou comitês de subespecialidade dessas sociedades envolvidas. Foi esta a razão pela qual tive o cuidado de selecionar para o número passado da revista (Fevereiro de 1999) três Consensos que eram não somente originais, atuais e de grande interesse, mas que também traziam o respaldo das sociedades interessadas, comprovadamente ouvidas a respeito.

Este cuidado do editor e do Conselho Editorial visa prevenir que o leitor seja informado sobre o tema em pauta de maneira precária, superficial ou mesmo displicente, pois em tese qualquer grupo de auto-intitulados "experts" poderia se reunir e definir um Consenso sobre qualquer tema.

Ocorre, como pode ser visto neste número da revista, que mesmo contando com o aval e o respaldo da sociedade envolvida, determinados assuntos não parecem estar tão consensualmente definidos ou decididos. Tanto na sessão Perspectivas como na sessão de Cartas ao Editor deste número da revista, Nogueira, Fontenele \& Aguiar e Eduardo Pimentel Dias discorrem sobre tópicos e detalhes que não parecem ter sido bem assentados, e que, portanto, devem merecer uma resposta e talvez alguma revisão por parte dos autores do Consenso sobre Diabetes Gestacional.

Tendo conversado previamente com a diretoria da Sociedade Brasileira de Diabetes, obtive informalmente seu aval aos termos dos referidos Consensos em Diabetes, mas, ainda assim, algumas questões poderiam ser levantadas por nosso leitores e aqui estão algumas delas: 1) Será que foi ouvido um número representativo de especialistas? Ou pelo menos os principais "experts" brasileiros no assunto? 2) Os participantes deste Consenso foram realmente representativos da comunidade que lida com este tópico? 3) Será que foram consideradas todas as possibilidades, procedimentos e condutas frente a um assunto tão sensível e delicado? 4) Não teria sido conveniente (se não obrigatório) ter feito uma chamada prévia da realização deste (ou de qualquer outro) Consenso, convidando para colaborar e opinar espontaneamente "experts" e outros interes- sados no assunto? 5) Deveríamos ter garantido por escrito e oficialmente a anuência e endosso das Sociedades ou Departamentos de Especialidade envolvidos?

Estes questionamentos estão em aberto e, como gostaríamos de continuar publicando outros Consensos de interesse para o Endocrinologista, solicito a opinião dos caros leitores para que possamos definir uma política democrática, mas segura e transparente, satisfazendo toda a comunidade. Coloco aberta a sessão de cartas ao editor para avaliar esta questão e procurar respaldo para a seguinte iniciativa: uma primeira versão de qualquer novo Consenso deve ser publicada apenas em caráter provisório e oficioso; após terem sido ouvidas críticas, comentários e sugestões (dentro de um período razoável de tempo), especialmente daqueles que não puderam participar diretamente de sua confeç̧ão, devesse ser revista e reformulada para, somente então, ser publicada como a versão definitiva, expressão oficial e representativa da posição da sociedade.

Adicionalmente, e talvez tão importante, certas arestas devem ser obrigatoriamente aparadas para que não se contemplem na formalização destes Consensos interesses meramente comerciais ou políticos.

Antes de terminar - e mudando completamente de assunto -, gostaria de comemorar a introdução neste número de duas novas sessões na revista: "Memórias" e "Caso Especial". A primeira visa relembrar e prestar uma homenagem a colegas ou pessoas que marcaram sua presença em nossa sociedade, seja por seu valor pessoal seja por suas contribuições, ou ainda rememorar fatos históricos e pitorescos acontecidos no passado envolvendo nossa sociedade e/ou seus associados. Em "Caso Especial", um tema atual e provocativo é discutido em torno de um caso elucidativo previamente apresentado, culminando com uma discussão aberta entre vários especialistas, fazendo perguntas ou comentários que poderiam estar sendo formulados pelo próprio leitor, enriquecendo a exposição daquele tema. Todos os colegas poderão contribuir com matéria para a sessão "Memórias", e todos os serviços da especialidade, ligados a uma escola médica ou universidade, estão convidados a participar da segunda, enviando os transcritos (previamente editorados) de suas reuniões médico-científicas oficiais. A sessão "Caso Especial" está sendo ofertada ao 
público leitor graças ao apoio e ao patrocínio especial da Biobrás S.A., a quem manifestamos publicamente nossos agradecimentos.

PS: Peço desculpas publicamente pela demora no envio deste número da revista. Nem mesmo o Editor-chefe dos ABE\&M está imune aos inconvenientes vírus despejados pela Internet. Por mais cuidado que tenha tomado (programas anti-vírus atualizados, "backups" freqüentes, eliminação de mensagens suspeitas), ainda assim fui "infectado" por um deles e tive o disco rígido do meu computador totalmente apagado. Como perdi grande parte do material já editorado e preparado para esta edição, tive que refaze-los integralmente, tendo extrapolado mais de duas ou três semanas do prazo tolerável para impressão e distribuição. 